\title{
Privilege and Property: The Political Foundations of Failed Class Formation in Eighteenth-Century Austrian Lombardy
}

\author{
DYLAN RILEY \\ Department of Sociology, UCLA
}

\section{INTRODUCTION}

The distinction between state and civil society is deeply rooted in both sociology and political theory (Barkey and Parikh 1991:525; Bobbio 1999:115; Habermas 1989:19). Even thinkers who argue that civil society and the state 'interact' often retain the basic conceptual opposition between the terms. Barkey and Parikh go so far as to characterize recent work on the state as "the state-society literature" (1991:524). Within sociology, however, there is less theoretical discussion of what connects state and society-political societyor the way that interests in civil society are constituted as claims on the state. But as the Sardinian Marxist Antonio Gramsci pointed out in his Prison Notebooks, and the German sociologist Max Weber is his essay on class, status and parties, political society is reducible neither to interests in civil society, nor to the state (Gramsci 1971:138-40; Weber 1946:194; see also Poulantzas 1976: 95; Przeworski 1985:67; Stepan-Norris and Zeitlin 1991:1153; Wright 1978: 103, 222).

Following in this Gramscian and Weberian tradition, the central theoretical point of this paper is to show how the structure of political society matters for group formation. More specifically, this paper addresses the question: what is the autonomous effect of political society on class formation, understood as the degree to which a group with a common relationship to the means of production organizes itself politically on the basis of that relationship? My main theoretical argument is that a political society, in which actors make claims on the state in terms of privileges attached to residence, rather than property ownership, inhibits class formation even when other factors, such as the relations of production, state pressure, and culture, promote it. Where such a political organization is not broken, class formation will not occur even in the presence of strong economic, state-centered, and cultural pressures. 
To investigate my claim I draw evidence from a case, eighteenth-century Austrian Lombardy (1714-1796), in which an urban patrician nobility heavily involved in capitalist agriculture, under constant pressure from a state desperate to extract more taxes from the province, and increasingly influenced by enlightenment culture, did not organize itself politically on the basis of common ownership interests. In short it did not form as a class. I find this outcome surprising from the perspective of economic, state-centered, and culturalist theories of class formation. I suggest that the case provides support for the claim that political society, the way that interests in civil society are transformed into claims on the state, has relatively autonomous effects on class formation. For, I argue, it was the patrician form of political organization, specifically that political claims could be made only in the form of a legal defense of local privileges that undermined the process of class formation in Austrian Lombardy.

\section{CONCEPTS AND THEORIES}

My argument is based on the conceptual isolation of political society from civil society and the state. Political society, I suggest, should be thought of as a filter in which interests in civil society are transformed into claims on public power. Political society is, at least potentially, autonomous from the state and civil society. By that I mean that the way that interests become political claims can vary independently of either those interests themselves or the public authority on which those claims are being made (Gramsci 1971:269-70).

Thus, in this paper I argue against three forms of reductionism - societal reductionism, state reductionism and cultural reductionism. Class formation is neither an automatic outcome of class interests (Bukharin and Preobrazhenky 1969:105-10), nor an automatic outcome of the interaction between class interests and state structures and policy legacies (Skocpol 1985:26-27; Weir and Skocpol 1985:119), nor an automatic outcome of the development of classconsciousness through an ideological mediation of experience (Lukács 1971: 163; Sewell 1985:58). Classes, to put it with Thompson (1963:9), 'happen' politically. But that does not mean that I retreat to a voluntarist explanation of class formation. Political society, I argue, is a structure having independent effects on class formation. My claim is modest-I do not suggest that relations of production, states, or culture, are unimportant in class formation, but simply point out the importance of identifying political society as an autonomous structure.

To link my argument to empirical evidence I develop indicators for both class formation and political society. By class formation, as noted, I mean the extent to which a social group with a common relationship to the means of production comes to act politically on the basis of that relationship. Of course there may be other forms of 'classness' aside from concerted political behavior, such as consumption patterns, attitudes, and forms of speech and dress. But class analysis since Marx (1978:474) has always taken political behavior as its central ex- 
planatory problem. Thus, as indicators for class formation I use evidence on noble political behavior. The first kind of evidence I exploit is writings on politics and economics. The second is noble reactions to reforms that promised a decrease in their political power in exchange for economic advantages. I show that class formation did not occur in eighteenth century Lombardy. There is little evidence of class solidarity among large Lombard landholders. Rather landholders, even those most influenced by enlightenment thought, persisted in acting politically as patricians.

Political society, my explanatory factor, in this essay will mean in the eighteenth-century Lombard context, the provincial municipal governing councils. These, as I will show, were the key institutions that allowed interests in civil society to become claims on the state in this case. Despite enormous pressure from the Austrian State, booming agrarian capitalism, and the increasing importance of enlightenment culture, political society changed little in eighteenthcentury Lombardy. Patrician political institutions were sometimes put on the defensive, but they re-emerged at the first sign of weakening from the central state.

The main argument of the essay then, is: to the degree that political institutions based on privileges attached to residence persisted, the Lombard nobility tended to act as a municipal patrician caste, and not as a class making political claims on the basis of land-ownership.

\section{CASE SELECTION AND METHODOLOGY}

The method of historical investigation that I use in this paper is called Negative Case Methodology (Emigh 1997), in which the researcher selects a case the outcome of which is anomalous from the point of view of a set of existing theories. The case is used not to refute the theories, but to extend what Lakatos calls a research program through an incorporation of the anomaly (Lakatos 1981:116-17; see also Burawoy 1990:777). In this case, the research program being advanced is class analysis. Sociologists are often un-self-consciously Popperian in their methodologies. This leads to attempts to falsify research programs with anomalies. As Lakatos pointed out, however, "neither the logician's proof of inconsistency nor the experimental scientist's verdict of anomaly can defeat a research programme in one blow" (1981:118). The test of a research program is whether, within the terms of its core postulates, it can expand to explain the anomalies.

Negative Case Methodology has three merits. First, it is effective at isolating decisive factors that remain hidden in positive cases. In particular, in cases where class formation happened, but the economy, the state, culture and political society all promoted the outcome, it is difficult to appreciate the importance of any one of the factors. Using a negative case, in which all the factors that have been theorized to lead to the outcome were present, but the outcome did not occur, allows one to identify further factors that may have led to the out- 
come in the positive cases. The second merit of Negative Case Methodology is that it allows the scholar to draw general theoretical implications from case studies. This means that scholars can treat historical evidence with the care that is often lacking in broader comparative work, but can still speak to broader theoretical issues. In this instance, if political society is important in the way that I suggest, theories of class formation deployed to explain positive cases could benefit from an incorporation of this factor in their own explanations, and thus a theory generated on the basis of a single case can be deployed across contexts. Finally, Negative Case Methodology, by relaxing the Popperian view that science advances through falsification, allows for a more productive use of intellectual energies than the Popperian orthodoxy. With Lakatos I take the point of view that research programs expand through the construction of new theories that are compatible with a set of core postulates of the research program, and that successfully incorporate anomalous evidence. My intellectual energies are therefore devoted to the extension of theory rather than an impossible refutation of it. In addition to its theoretical contribution, my essay, thus, seeks to demonstrate the usefulness of Negative Case Methodology in historical comparative research.

In this paper the negative case is the failure of class formation in eighteenthcentury Austrian Lombardy. I purport to explain the failure by the existence of particular kind of political society. If my theory is right, however, my claim about the effect of political society on class formation might be used in contexts other than eighteenth-century Lombardy.

\section{PLAN OF THE ESSAY}

The methodology of this essay necessitates a particular organization of the historical material that differs sharply from the standard 'hypothesis-test' framework of sociology that assumes the validity of a Popperian logic of falsifiability - the point of Negative Case Methodology is not to falsify theory but to extend it. Thus I pursue the strategy of pushing an economic explanation, a political explanation, and a cultural explanation as far as they can go. In the end I do not show that these theories of class formation are wrong but that singly, and in combination, they are not as general as they claim to be. Since they all predict class formation as an outcome for Lombardy, yet class formation did not occur, they must be extended to take explicit account of the structure of interest representation-political society.

The economic explanation, derived from the determinist Marxism of the right wing of the third international, would suggest that the embourgeoisment of the nobility should have been a result of a transformation in the relations of production (Bukharin 1969:105-1010). However I show that Lombard nobles were deeply involved in capitalist agriculture at both the beginning and end of

${ }^{1}$ Economic determinist explanations of class formation are extremely rare within Marxism. 
the century. Since relations of production were, roughly speaking, capitalist, it is a mystery from the point of view of this theory why Lombard nobles did not organize as an economic class.

The state-centered explanation would suggest that state policies would lead to the formation of a new class identity through pressure to standardize administration and eliminate privileges (Skocpol 1973:18; for a more nuanced statement of this general view see Mann 1986:481). Lombardy is a classic case of a state-centered attempt to eliminate privileges, but this did not result in class formation. Rather, Lombard, and especially Milanese, nobles bitterly fought for their 'feudal' privileges throughout the century.

Finally a culturalist explanation might predict class formation as an outcome of the enlightenment transformation of noble self-conceptions in the mid-eighteenth century (Katznelson 1995:146; Lukács 1971:155; Sewell 1985:76-81). Milan was the major intellectual center of the Italian enlightenment, and younger nobles themselves led the movement. Yet the enlightenment political program generated little wider support among the nobility, who retained their patrician privileges rather than becoming an agrarian 'third estate.'

Thus from the point of view of each explanation taken separately, the outcome - the absence of class formation among the Lombard capitalist nobility-is anomalous. The outcome is even more anomalous when one considers the explanations together. It is surely plausible that capitalist development, pressure from a centralizing state, and a sweeping cultural transformation mutually heightened one another's effects. Given this, why didn't class formation occur?

I suggest that the problem is that these theories do not adequately treat political society - that is the way in which interests are translated into claims on public power. Political society in Austrian Lombardy remained bound to the framework of municipal government based on a structure of legal privileges attached to residence. This system did not allow class interests to be translated into political claims. Politics in Lombardy overwhelmingly took the form of a struggle among patriciates possessing different privileges according to their residence. There was therefore no political basis for class formation (for discussion of the political bases of class formation see Poulantzas 1976:95; Wright 1978:241).

\section{AGRARIAN CAPITALISM IN EIGHTEENTH-CENTURY LOMBARDY}

This section shows that the Lombard nobility was increasingly dependent on capitalist agriculture throughout the eighteenth century. In an economic sense, it could be said that the nobility was an agrarian capitalist class. However there existed some politically determined forms of exploitation as well. I suggest that these became less important over the course of the eighteenth century.

Lombard nobles depended on two institutions of surplus extraction. There was a set of economic institutions including land-ownership and contracts, and 
a set of political institutions including control over the right to extract taxes and fines. The evidence suggests a secular decline in surplus extraction through political mechanisms over the course of the eighteenth century. Thus, in an economic sense the Austrian nobility was more of a capitalist class at the end of the century than at its beginning.

The economic geography of Lombardy in the eighteenth century was divided between the hills and the high plain dominated by sharecropping, and the Lombard low plain organized into large consolidated farms worked by wage labor and owned by the nobility. In this section, I first sketch the economic history of Lombardy from the seventeenth century. Then, to assess the class position of the nobility, I describe the tenurial arrangements predominant in the different areas of Lombardy. I then use data from the land tax survey of 1733 to show what the social composition of land ownership was in those areas.

Agrarian production in the Lombard low plain was highly developed by the seventeenth century, while the urban economy was in decline. Throughout the century, the urban silk and wool industries declined because their products could not compete with French and English ones. By 1635, Milan was an important market for French silks (Sella 1979:80). A shift in consumer tastes from carded to worsted fabrics damaged the Lombard woolen industry (Sella 1979: 80-81). The Lombard urban guild-regulated manufactures could not compete with their counterparts in England and France because of high labor costs and traditional production practices (Sella 1979:102). In the countryside, the story was different. Entrepreneurs established rural textile industries, papermaking, and metallurgy in the seventeenth century, and made improvements in agriculture (Sella 1979:111-16). Although evidence for the seventeenth century is thin, ${ }^{2}$ scattered examples may indicate a general trend (Sella 1979:120). On one estate in the low plain (bassa pianura) cereals receded, and were replaced by fodder crops, indicating an increase in livestock raising. In addition, middle tenants reclaimed wasteland, and increased crop production and the proportion of livestock to surface area (Sella 1979:117). On an ecclesiastical estate in Cremona, a comparison of tenancy contracts-one from 1658 and another from 1681 - shows the increasing involvement of landowners in production practices. While the 1658 contract stipulated that the land should be worked according to the custom of the district, the 1681 contract specified that the tenant must give five furrows to the land, a reference to how much arable land must be plowed (Sella 1979:118). The growing concentration of land in the low plain in large estates facilitated these processes. From the fourteenth century, agrarian entrepreneurs expropriated small holders and land tended to concentrate in large estates (Grab 1980:141-42; Grab 1989:51-52).

These improvements in production practices, although not the social rela-

2 Sella (1979: 120) suggests that all the available evidence points to progress and improvement throughout the century. 
tions that undergirded them, were partially a response to market pressures outside of Lombardy. The same processes that ruined the Lombard manufacturers, the growth of foreign manufactures, opened up new markets for raw materials produced in Lombardy such as raw silk, flax, and hemp (Sella 1979:124). In addition to this trade, there was an interregional system of markets. Peasants and agrarian entrepreneurs marketed grain, dairy products, and fish in urban centers. Specialized production for the market had increased to such an extent that by the seventeenth century many peasants did not grow enough wheat for their own subsistence (Sella 1979:106).

While this sketch suggests that production practices in agriculture were partly capitalist before the Austrians arrived in Lombardy in 1708, the best evidence for the class position of the Lombard nobility is, for the eighteenth century, from the land tax survey of 1733 .

Here I provide a sketch of the tenurial relations in the low plain as they existed in the eighteenth century, and then provide data on the percentage of land owned by nobles in the low plain where these agricultural relations were predominant. The category of 'nobles' includes the feudal service nobility, the Milanese patriciate, the provincial civic patriciates, and the Spanish service nobility.

By the eighteenth century, large capitalist tenants, landlords, and agrarian wage laborers were the three main classes in the Lombard low plain (Bianchi 1976:32; Grab 1980:140-42; 1989:51-52; Roberts 1953:68). The Lombard nobles received income from capitalist agriculture in so far as they collected rent from capitalist tenants to whom they rented land, and sometimes as capitalist agriculturists themselves (Grab 1980:142). The typical tenurial arrangement of the low plain was a nine-year lease on a thousand pertiche ${ }^{3}$ piece of land. Rent was paid in money three times a year. The proprietor assumed no risk and did not manage the farm. Leases spelled out the responsibilities of the lessee, to ensure that tenants improved landowners' lands (Romani 1959:9798). The large-tenants employed wage labor on their farms (Grab 1989:52), as is indicated by the fact that more than three quarters of the population of the low plain was involved in wage work (Romani 1959:105). Wage labor in the Lombard plain came in three main forms. Tenants or landowners hired salaried workers by the year or the month, daily workers by the year, and piece workers paid variable wages week-to-week. Farmers paid wages partly in money and partly in kind (Romani 1955:105-7). Some scholars suggest that the large tenants played a progressive role in Lombard agriculture. They invested in improvements, and brought new land under cultivation (Grab 1980:142).

What social groups owned land in the low plain? In 1730, according to data from the land tax survey, the nobility owned 72 percent of the surface area of the low plain divided into estates of over two hundred hectares. Further nobles

${ }^{3}$ One pertiche $=.15$ acres. Therefore, 1,000 pertiche is about 150 acres (Sella 1979: 175). 
comprised 75 percent of owners of estates over two hundred hectares (Romani 1959:72-73). The nobility owned 46 percent of the total surface area of the low plain. Non-nobles owned only 32 percent of this surface area, while they comprised 91 percent of the proprietors who owned land of less than one-quarter of a hectare (Romani 1959:72-73). Thus, the nobility owned most of the largest estates in the low plain. Furthermore, the weight of the low plain in the Lombard political economy was decisive. The plain encompassed about half the surface area of Lombardy and over 60 percent of the population (Romani 1959:23). The predominance of capitalist relations of production in the low plain combined with the fact that nobles owned most of the large estates here, and that this was the most important sector in Lombard agriculture in terms of surface area and population involved, suggests that the Lombard nobility was gaining much income from market-dependent capitalist agriculture by the early eighteenth century.

In the dry plain (pianura asciutta) and the foothills, the proprietors provided land, animals, seed and implements in return for a portion of the yield, dues in kind, labor services, and fines (Grab 1980:135). As market opportunities for wheat and silk increased during the eighteenth century the condition of the peasantry in these areas worsened. Originally, peasants cultivated in extended family units working under the supervision of a male head of household. However, to encourage competition among the peasantry, and thus to drive up dues, landlords subdivided these plots. In addition they shifted dues in kind to cash crops (wheat and silk) (Grab 1980:136; Romani 1959:87). In some cases in these areas middle tenants leased land from nobles. However they did little to change methods of production and remained middlemen between owner and peasant (Romani 1959:91).

These kinds of tenurial arrangements predominated in the foothills of the Alps and the high plain. The nobility owned 100 percent of estates over two hundred hectares in the high plain (Romani 1959:72-73). In the foothills no estates over two hundred hectares existed. Noble proprietors constituted 44 percent of owners of estates between forty and two hundred hectares, and owned 56 percent of the surface area divided into estates of this size (Romani 1959:7273). Overall, the nobility owned 49 percent of the surface area in the foothills and 42 percent of the surface area in the high plain (Romani 1959:72-73).

Thus, the Lombard nobility controlled two main kinds of economic lever for gaining an income. In the low plain noble incomes were tied to the capitalist exploitation of wage labor. In the hills and the dry plain nobles, or middle tenants, squeezed the peasantry for dues, fines, and payments in kind. This evidence suggests that nobles, and the tenants to whom they leased, used contracts and land-ownership to appropriate a surplus from the peasants and the agricultural proletariat.

Especially after the long post-1749 peace (the end of the War of the Austrian Succession), and price rises of the 1760s, agricultural progress was steady 
in Lombardy. Evidence from the lands of the counts of Barbiano di Belgioioso, large landowners in the low plain, show that fallow lands were reduced over the century. In 1670, 28.7 percent of the land was left fallow, by 1766 this figure was reduced to 8.23 percent. These reductions occurred under the management of larger middle tenants oriented toward the market who linked cattle raising to cultivation, as is shown by the concomitant increase in the forage area from 13.23 percent of the land in 1670 to 35.77 percent in 1766 (Cafagna 1959:394). Thus over the eighteenth century the Lombard nobility was becoming an increasingly rich class of agrarian capitalists. However, nobles supplemented their income with some rent squeezing.

Overlaying these property relations was a set of fiscal rights that had a 'feudal' logic. According to one estimate there were 758 'alienated royal revenues' that consisted mostly of fines on consumer goods (Capra 1987:302). The rights to these fines were sometimes associated with a feudal jurisdiction, but sometimes were owned separately. A 'fief' was essentially a set of fiscal rights and was not a form of economic ownership. Even within infeudated areas there existed allodial land which, although subject to feudal dues, was privately owned (Romani 1959:52; Sella 1979:168).

It is not obvious that interests deriving from these feudal rights were compatible with those deriving from the ownership rights described above. As Carlo Capra argues, the redemption of the alienated royal fiscal rights, the replacement of venal offices with salaried officials, and the reduction of loans and tax farming, flushed the Lombard nobility with cash, lowering the interest rate from 5-6 percent to 3-3.5 percent. Noble landowners could now invest in their lands, as the powerful Litta family did (Capra 1987:413). Further, the proliferation of fiscal rights undermined the development of a unified national market. This suggests that the feudal logic of extraction, depending on political levers and tying up capital that could be profitably employed in agriculture, was in tension with the ownership logic embodied in the contractual regime in the hills and the low plain.

This analysis then suggests that at the beginning of the eighteenth century the Lombard nobility was situated between two economic class positions that were not obviously compatible. On the one hand it employed economic mechanisms, ownership rights and contracts, to extract surplus from peasants, tenants and wage laborers. At the same time it employed political mechanisms, the control of fiscal fiefdoms, and the ownership of alienated royal dues.

On the basis of this complex set of property relations a strictly economic explanation of the failure of the nobility to act politically as an agrarian capitalist class could be formulated. Lombard nobles were a ruling class that drew income from two apparatuses of surplus extraction. They were partially a feudal class, and partially a capitalist class. Their economic interests were therefore best served by the existing set of arrangements. There is a great deal of force to this argument, and the issue merits further historical research. Still there is an 
overall problem with it. When one considers the century as a whole there is little doubt that the properly feudal mechanisms of extraction were becoming increasingly less important. Tax reforms undertaken by the Austrian government at mid-century undermined the Lombard system of fiscal feudalism (Capra 1987:304). Further there was a long boom in grain prices after the 1740s. But this did not lead in the short-term to a reorganization of the nobility along the lines of their interests as agrarian capitalists.

\section{FROM A SOCIETY OF ORDERS TO ENLIGHTENED ABSOLUTISM: POLITICAL SOCIETY AND THE STATE IN LOMBARDY}

Next I establish the central paradox upon which my paper is built: the absence of any spontaneous political movement from below to represent noble interests as agrarian capitalists despite an attempt to institute just such a system from above. The Austrian state functionary Pompeo Neri in the 1750 s initiated a systematic attempt to establish a political order in which landed wealth would form the basis of interest representation. This was a determined attempt to create institutions in which the ownership interests of nobles would be directly represented politically. It was a project of class formation from above. Given the capitalist character of the Lombard economy, surprisingly, no significant group of the Lombard nobility ever adopted this project. Put differently, the combined pressure of capitalist agriculture, and a systematic attempt to create class-based political institutions on the part of a central absolutist state, did not lead to class formation in the Lombard case.

Lombardy was organized as a city-state system (Sella 1979:30) in the seventeenth and eighteenth centuries. Each city in Lombardy controlled a rural area outside its walls called either a ducato, a principato, or a contado. In the seventeenth century, there were eight of these city-state areas: the ducato of Milan, the principato of Pavia, the contadi of Cremona, Lodi, Como, Novara, Allesandria and Tortona (Capra 1987:3; Grab 1983-1984:45; Sella 1979:30). By the mid-eighteenth century, after the War of the Spanish Succession and the war of the Austrian Succession, there were only six city-states left (Cremona, Pavia, Casalmaggiore, Como, Lodi, and Milan) (Grab 1983-1984:45). In each one, a local municipal oligarchy or patriciate controlled the province through its own laws and administrative structures (Grab 1983-1984:47). In them, the urban center dominated the countryside in three ways. First, city residents monopolized administrative and judicial offices. Second, the oligarchies taxed lands owned by rural residents at higher rates than urban owned lands. Third, the patriciates forced rural areas to supply the cities with raw materials, means of subsistence, and taxes (Sella 1979:30).

Lombardy had three levels of administration. The governor, a Habsburg representative, held the highest authority. Before 1708 the governor was a Spaniard, while after that he was an Austrian. In addition to this administrator there were magistracies with state-wide competence that ruled through their power 
to arbitrate among the interests of conflicting parties. The key institution in this system was the Milanese Senate. The Senate had the power to arbitrate between conflicting legal decisions made at the provincial level. The stylus, a compilation of judicial decisions made by the senate, comprised Lombard positive law. Thus, legislative authority, in classic feudal style, was exercised as judicial authority (Capra 1979:318; Cavanna 1980:621; Grab 1983-1984:46).

Below these institutions were magistracies in the provinces dominated by the local patriciates. Below the provinces were 1,492 communal governments that typically consisted of a local council (Grab 1983-1984:45; Klang 1977:4445). This system institutionalized three levels of domination. The Austrians dominated Lombardy as a whole, Milan dominated the provinces, and the cities dominated the countryside. In the Lombard context, political society means the set of provincial and communal institutions through which daily politics was pursued.

Control over the Lombard administration, rather than formal political rights, was the key to political power in Lombardy in two ways. First, through this control the Milanese patriciate limited access to its ranks by limiting access to administrative posts that were a prerequisite to patrician status (Pino 1979:359; Roberts 1953:65). Second, the ruling class exercised power through this administrative monopoly. This was true both directly and indirectly. Directly both the Milanese patriciate and the provincials staffed the magistracies that performed all of the administrative work of the provinces (Cavanna 1980:621; Grab 1983-1984:46; Sella 1979:31). Less obvious, but crucially important, the Milanese patriciate depended upon the existence of a multitude of conflicting privileges so that the senate could play the role of arbitrator between the squabbles of the provinces (Cavanna 1980:621).

All power was thus exercised as a privilege attached to residence, and at the apex of the system that power depended on the existence of other privileges in order to function. Political struggles between the Lombard ruling class and the Austrian state, and among the Lombard ruling class itself, tended take the form of legal struggles over privileges.

\section{ADMINISTRATIVE REFORM AND PATRICIAN REACTION (I755 - I 758)}

The communal reforms of the 1750 s tied political power at the communal level directly to ownership of land. This transformed the structure of authority at the local level since the government of the communes was no longer based on particularistic privileges, but rather was based on economic ownership. Pompeo Neri was a reformer whom the governor, Gianluca Pallavincini, selected to complete a land tax project begun in the early part of the century and establish a system of exaction (Klang 1977:24). Neri thus undertook two broad tasks: he first established commercial personal taxes and secondly he established new administrative structures for the communes to levy the taxes.

The communes were rural administrative organizations below the five main 
provinces. The main responsibility of these institutions was to repartition taxes. Before the reforms, councilors of the communes had usually been the agents of the most powerful owner in the commune (Capra 1987:170). These persons were often illiterate and without landed wealth of their own (Mozzarelli 1982:50). Thus communal government had been a mechanism through which powerful and corrupt urban landowners could exempt themselves from paying taxes. From 1749 to 1755 Pompeo Neri, under the direction of Vienna, tried to reform the communal administration because without a reform in the methods of partitioning the tax burden, all land could not be taxed equally. Neri wanted a communal administrative structure that would assure that assessment would follow the value of land as declared in the Austrian cadastral survey redacted early in the century, called the censimento. To this end, on 30 December 1755 the Austrian government announced an administrative reorganization in which the 1,492 communes of Lombardy were to be reconstituted as 157 delegations (Grab 1983-1984:50; Klang 1977:52; Mozzarelli 1982:31-34). Within each delegation was an executive organization called the convocation that elected fiscal officials who were to administer the land tax or on the basis of the censimento.

The convocation was comprised of all landowners who appeared on the censimento (Grab 1983-1984:50-51; Klang 1977:46-47). The delegations were each administered by a state official, the delegate councilor, who represented the power of the Habsburg state at the communal level and came from Milan, although his salary was paid by the communes (Klang 1977:53). He was required to be either, a doctor, a notary, an engineer, or a land surveyor (agrimensore) and he could not be an agent of any individual property owner (Capra 1987:172). This was to assure that the delegate councilor did not hold his position as a favor from one of the powerful landowners. The delegate councilor was the representative of Vienna at each one of the convocations in his delegation. One of the key aims of the reform, then, was to raise the social level of local administration, making local administrators less subject to the very largest landholders and more self-governing (Mozzarelli 1982:50).

However, and this is the key point, this reform did not undermine landowners' political power as landowners. Rather it transformed this power, from status privilege into class power based on wealth. Political predominance in the communal councils was to be based on the ownership of property as recorded in the censimento. Anyone who did not pay taxes due to exemptions based on his political status was excluded from participation in the convocations (Mozzarelli 1982:103). The chief executive official of the commune, the deputato dell'estimo, whom the convocation elected, was required to be among one of the three wealthiest landowners in the commune (Capra 1987:171; Klang 1977: 48; Mozzarelli 1982:67). To ensure that one of the three wealthiest landlords was indeed elected as a deputato, urban dwelling property owners (who might be the most wealthy landholders in their province) were allowed to send sub- 
stitutes (Klang 1977:48). Furthermore the other two kinds of convocationthat for payers of the commercial tax or merciminio, and the peasants' convocation for those who paid the personal tax-were subordinated to the convocation of owners. It was the landowners who drew up the tax roles of the personale and the merciminio that gave them power over both merchants and peasants (Klang 1977:51; Mozzarelli 1982:70-71). It is also true that besides reinforcing, on a basis different from urban privilege, the power of the landowners over the countryside, the new administrative structure allowed non-noble landowners to take part in the political process, and thereby broadened the political class. In Lombardy about twenty percent of the population owned land and these individuals all had a right to participate in the communal councils (Klang 1977:48). ${ }^{4}$

The reforms of 1755 thus secured the political power of the large landowners, as landowners, in the countryside, while they undermined status privileges as part of the same process. They did so by stipulating that the largest landowners should hold the most important political positions in the commune. This political structure thus increased the dominant economic classes' authority over the peasantry.

It was crucial, however, that Neri largely failed to extend the principle of rule by wealth up from the level of the commune to the level of the provinces, that is, to the level of the city state governments themselves, although he attempted to do this from 1756 to 1758 . The best he was able to do was tie some seats on the provincial councils to a property qualification that varied province to province (Klang 1977:58-65).

The first discussions of the provincial reforms took place in March and April of 1755 . The basic aim of these reforms was to separate the civic administration of the city-states from the provincial administration, and to reform the provincial administration so that wealth rather than a status attached to residence, or some other privileged identity, became the criterion for representation. The giunta, or council, thus suggested the formation of a provincial delegation whose representatives would be chosen by the communal congregations, and approved by the giunta (Mozzarelli 1982:139-41).

Only two of the provinces, Cremona and Pavia, however responded to the giunta's proposals. In both provinces before the reforms powerful Milanese landholders were organized as a separate status group-the Milanese interests. In both cases the local patriciate hoped to increase its power by accepting the unification of the administration of the province. In Cremona this attempt was successful. Given the economic strength of the Cremonese patriciate, the provincial council that, like the local congregations, was based on wealth, worked

\footnotetext{
${ }^{4}$ One indication of the effect of these reforms on the politicization of non-noble landowners is given by their behavior under Leopold in 1791 when in Lodi and Como they sent a supplication to the sovereign asking for representation at the provincial level (Capra 1984: 609).
} 
in its favor. In Pavia however, while the reform formally recognized the independence of the urban patriciate, real political power slipped from its hands into those of the largest wealth-holders, many of whom were Milanese, organized in the provincial congregation (Mozzarelli 1982:175).

Neri's greatest failure however was that he was able to do nothing to reform Milanese government. The principle of rule by birth and the patrician monopoly on administrative offices remained untouched (Mozzarelli 1982:199). Since his project remained incomplete, as I show below, the reorganization of communal government, combined with the conservation of patrician power, paradoxically re-enforced regional divisions among the Lombard nobility rather than superseding them. This failure had absolutely decisive consequences for the political organization of the Lombard nobility, and it had a number of causes. First, the Austrian plenipotentiary, Beltrame Cristiani, was deeply conservative and committed to patrician rule. Second, Cristiani was at the time engaged in complex negotiations with the Vatican, and he did not want any reform that might subject church lands to taxation. Third he was under pressure from Maria Theresa to bring the expensive census project to a close because of the mounting cost of the seven years war. In any case, Neri was released in 1758 to return to his native Tuscany.

The reforms of the 1750s constituted a more or less systematic attempt to create class institutions for the nobility. Political power, according to Pompeo Neri, should derive from land ownership. Given the overall structure of the agrarian economy in Lombardy, that agrarian capitalism was highly developed, the reaction of the nobility to these reforms is surprising. For, far from embracing Neri's projects, the later 1750 s was a period of bitter noble resistance.

After Cristiani's death in July of 1758 the Milanese patriciate regained control of the state, as the reactionary president of the Milanese senate, Giovanni Corrado de Olivera, became acting governor (Capra 1987:188). Corrado de Olivera presided over a systematic legal challenge to the administrative reforms. The nobility responded to the publication of the final version of the cadastral survey by issuing thousands of legal challenges (Capra 1987:189). To put it briefly, nobles continued to pursue the old strategy of juridical struggle for the protection of privileges.

This reaction however was short lived. It was reversed in 1760 with the arrival of count Firmian as the new plenipotentiary. Firmian partially reversed the patrician reaction with the enactment of a universal proportional land tax on 1 January 1760 . The tax was apportioned through a series of aliquots or divisions. First the burden for the state as a whole called the "universal and royal burden" was drawn up. This partition was then divided between the provinces, and the provincial burden was divided between the communes. At each level of apportioning there was an administrative organ responsible for the work, and a royal representative who oversaw the process. At the level of the state, the Congregation of State determined the burdens to be carried by each province. Its 
work was monitored by the Supreme Council on the Economy. At the level of the province, the provincial administration was used to apportion taxes among the communes. Its work was monitored by the delegate councilor. At the level of the commune, the communal organization distributed the burden among individual taxpayers, and was supervised by the delegate councilor. The process thus institutionalized both self-administration and state control (Capra 1987: 197-98).

Firmian, however, struggled against the Lombard nobility and their patrician organizations. Although the new administrative order was explicitly designed to strengthened noble political power based on land ownership, the immediate reaction of the Milanese patriciate, at least, was to attempt to re-institute the old order at the first opportunity. This is especially surprising when one considers the evidence I have presented on the political reforms together with the economic evidence. The Lombard nobility was now an increasingly rich agrarian capitalist class. But the nobility, and especially Milanese nobility, continued to act as a noble status group protecting political privileges through juridical struggle.

To summarize, then, the evidence suggests that eighteenth-century Lombardy is a negative case, both from the perspective of an economic theory of class formation, and from the perspective of a state-centered theory. A nobility that was heavily involved in capitalist agriculture, combined with a state that explicitly tried to reorganize this nobility along class lines, did not generate class formation among the nobility in eighteenth-century Lombardy. Neri's failure to reform the structures of government at the provincial level was decisive. The patricians, while not able to entirely role back Neri's reforms, maintained their control over the municipal governments at the provincial level. The paradox then should now be clear. An increasingly rich agrarian capitalist class organized itself politically as a group of urban patricians. This outcome might appear less paradoxical, however, when culture is considered. So I now turn to an analysis of the impact of the Milanese Enlightenment on the political selforganization of the Lombard nobility.

\section{REFORM AND ENLIGHTENMENT}

One obvious explanation for the lack of class formation among Lombard agrarian capitalists in the eighteenth century might be that the nobility lacked a class ideology, or class culture. This argument has considerable initial plausibility. The culture of the Lombard nobility was highly legalistic and conceived of the political order as a series of contracts among status groups (Capra 1987:2004). It is no accident that the challenges to the Neri giunta that I discuss above all took the form of claims to protect ancient legal privileges. Thus in the early eighteenth century the Lombard nobility clearly lacked a class ideology.

The cultural argument would imply, however, that a change in the culture should have led to class formation, especially given the overall economic and 
political conditions. This section investigates the plausibility of such an argument by analyzing the impact of the Italian Enlightenment on the political selforganization of the Lombard nobility.

There is considerable evidence that noble culture in Lombardy changed rapidly after the late 1750s. The first sign of a change within the ruling nobility was the establishment, in 1758, of the Academy of Fists (Accademia dei pug$n i) .{ }^{5}$ This organization was comprised of a group of young patricians who were interested in wide-ranging political reforms in Lombardy and state employment for themselves (Venturi 1969:736). In a double sense this group rejected the traditional political structures of the Lombard state. First, by seeking employment with the Austrian state, the members of the Academy of Fists rejected the typical career path of a young patrician through the legal colleges and then to service in the municipal government of Milan. Second, the members of the academy cultivated self-consciously informal relations of equality amongst one another in an attempt to prefigure the society of the future. Finally, they directly confronted the old structures with proposals for reform of the fiscal system, money, penalty, and law. The new noble self-consciousness often led to painful breaks within the patrician families. By the end of the 1760 s both the major figures of the Milanese enlightenment, Beccaria and Verri, were estranged from their families (Venturi 1969:647). Intellectually, the Academy became the local conduit for the European enlightenment. Pietro Verri was first introduced to enlightenment ideas during his time in the Austrian army during the seven years war where became friends with the English economist Henry Lloyd (Capra 1987:208).

The Academy of Fists was the first local political agent pushing for reform in eighteenth-century Lombardy. Franco Venturi suggests that the members of the academy (almost all sons of highly privileged Milanese nobles families) conceived of themselves as a political class in formation (Venturi 1969: 673). The ideology of the academy was expressed in the periodical Il Caffe published in 1764 and 1765 and in a variety of writings after that period (Woolf 1979:99). Between the years 1764 and 1766, this society gave a more consistent philosophical basis to what it saw as the 'improvisations' of previous reformers.

It is important, however, not to exaggerate the degree to which even the most progressive nobles adopted a 'bourgeoisie outlook.' Verri himself had idiosyncratic views that show that while he theoretically appreciated agriculture he badly understood it in practice. Verri completely misconstrued the function of entrepreneurship. He argued that the best way to increase production was to break up land into small plots. He was suspicious of the larger leaseholders and agricultural entrepreneurs who were probably the major engines of economic progress in Lombardy (Klang 1990:379). Cesare Beccaria was probably the

5 They were called the Academy of Fists because it was rumored that their arguments became so heated that the members often came to blows. 
only member of the Milanese School who understood the importance of entrepreneurship. However he did not develop his initial insights, and tended to see the peasants and landowners as the two most important classes in Lombard society, overlooking the enterprising middle tenants (Klang 1990:383). Further, there was a tendency even among the Illuministi to disdain manual labor as undignified (Capra 1987:436-37). Thus, while elaborating a new self-conception for the aristocracy as an ownership class, these figures still bore the traces of their ancestry.

Although initially this new 'bourgeois' cultural outlook was restricted to an intellectual avant-garde, some evidence suggests that by the 1770s it had spread. In 1782 Verri himself noted that, "every noble either by imitation, or opinion thinks differently from his ancestor" (Capra 1987:437). In 1776, partially in response to local demands, a patriotic society was founded in which nobles discussed agrarian problems (Capra 1987:338-39). Moreover, the number of young nobles who pursued ecclesiastical careers was declining, as was the practice of primogeniture (Capra 1987:437-38).

What were the consequences of this changing culture for the political organization of the Lombardy nobility? Any balanced view suggests that they mattered, but ultimately were unable to generate the kind of political break that could have led to class formation among the nobility. The Academy of Fists was potentially a new kind of political agent. It differed in organization and ideology from the older academies linked to traditional culture that had no connection with economic or social questions. The style of personal relationships among the members of the academy prefigured an egalitarian bourgeois society. But this political agent was ultimately defeated. The fundamental institutions of noble rule remained, until 1796, the Congregation of State and the Senate. These institutions remained impervious to the influences of the enlightenment.

The paradox of the Lombard case should now be clear. A nobility heavily involved in capitalist agriculture never organized itself in such a way that those interests found political voice. This is true despite Austrian state functionaries attempting to create institutions that would be based on common ownership interests, and a new 'bourgeois' culture sweeping the nobility from the late 1750s, generating a new political agent - the Academy of Fists. From the perspective of the theories of class formation that I outlined at the beginning of this essay, Lombardy thus constitutes a classic negative case.

\section{POLITICAL SOCIETY AND THE NON-FORMATION}

OF A LOMBARD AGRARIAN BOURGEOISIE

Why, then, was the Academy of Fists unable to transform the political organization of the Lombard nobility, that is, to transform the nobility from a patriciate into a class? As I have shown in the above three sections the economic conditions for class formation existed, the Austrian state was pushing the nobility 
to reform its political institutions, and a new enlightenment culture created a reformist noble political agency, the beginnings of a class project from within the nobility itself. This section shows that the movement to create a new classbased set of political structures failed because there were no adequate institutions for articulating such interests.

The enlightened nobles of the Academy of Fists discussed above never effectively developed a political strategy for social transformation. Although the major figures of the group drew up many projects for social and economic reforms, they developed an unworkable strategy for implementing them: alliance with the Austrian state. Enlightened despotism was for the Illuministi a surrogate for local political agency.

The clearest exponent of the strategy of enlightened despotism was Pietro Verri. While Verri was a committed anglophile and supporter of civil liberties, he was not a major proponent of political liberty, which he saw as unsuited to the Lombard context. The reason was that Verri feared that political autonomy in the Lombard context would simply re-enforce the old corporate divisions among the nobility, and between the nobles and the commoners. Up until the late 1780s the Russian court of Peter the Great with its alliance between philosophers and despot was Verri's political model (Venturi 1987:499). The particular structure of Lombard political institutions was thus reflected in the authoritarian bent of the early Milanese enlightenment. The intellectuals of the Academy of Fists were unable to identify any self-organized local political force that could become an agent of reform. As Verri wrote a ". . . dictator is needed to make reforms, not a senate" (quoted in Dipper 1980:876).

Enlightened despotism lost its attractiveness as a vehicle for reform when the Illuministi actually tried to work within the Austrian bureaucracy. As an institution for gaining state employment, the Academy of Fists was highly successful. Pietro Verri, its founder, held several important administrative posts, retiring only in 1786. Cesare Beccaria ended his career as a renowned economist and professor. Luigi Lambertenghi obtained a position in the department of Italy at Vienna. Gian Rinaldo Carli held positions on the Supreme Council of the Economy and in 1785 was a member of the cameral court (Venturi 1969: 673-75, 736; Woolf 1979:126). But these careers were administrative rather than properly political, and could not really lay the basis for class formation. With the despotic turn of Austrian absolutism under Joseph II in the 1780s, the original nucleus of the Illuministi disintegrated. Verri, for both personal and political reasons, was not well-suited to bureaucratic work. The Archduke Ferdinand referred to him as a failure as a functionary (Capra 1987:295). Gian Rinaldo Carli left the bureaucracy shortly after Verri in 1786.

The strategy of state employment decanted the intellectual energies of enlightenment reformers away from a properly political program toward technical treatises on state administration. Verri presented Carlo Firmian with a treatise on salt taxes, and Count Anton von Kaunitz with a treatise on the condition 
of commerce in the state of Milan. In this second report Verri argued for the abolition of tax farming in the interests of developing commerce (Limoli 1958:260). As a result of his report, Pietro Verri, along with Angelo Mantegaz$\mathrm{za}$, another patrician, obtained a position in a giunta established for the reform of indirect taxation (Capra 1987:224; 1979:341; Limoli 1958:261). Verri then struggled within the Austrian administration to push for further reform. During his appointment on the giunta for the reform of indirect taxation, Verri published the commercial balance of the state of Milan for the year 1752 without the authorization of Vienna (Capra 1979:343; Limoli 1958:260; Venturi 1969:695). Verri created a public stir with this publication, and Kaunitz, the Austrian plenipotentiary chastised him. Such conflicts became increasingly common through the later eighteenth century.

The enlightenment reformers' strategy of alliance with the state thus led quickly to frustration. The narrow dirigismo of Austrian absolutism could not really allow the expression of class interests politically. Rather the Austrians co-opted various groups within the nobility-conservatives and reformers. This led Pietro Verri in particular to turn later in life toward constitutionalism. It was self-organized society rather than a centralizing bureaucracy that could modernize Lombardy (Cuccia 1971:48). I return the consequences of this shift below.

There was, however, a second movement not coming from the Academy of Fists but from the provincial nobility that one might have expected to alter the political organization of the nobility. As the research of Alexander Grab on the liberalization of grain commerce shows, some provincial nobles wanted to do away with the whole system of tax privileges and commercial controls so that they could take advantage of price rises. Further there were elements within the Milanese patriciate itself that wanted to liberalize grain commerce (Grab 1985:190). But these interests were articulated in the Congregation of State. Here they could only appear as a defense of tax privileges, because this was an institution established for bargaining over how to distribute the taxes among the municipal 'publics.' Thus, as had occurred repeatedly in Lombard history, in the debate over reform of grain commerce the provincial nobles split off from the Milanese (Grab 1985:197). The potential alliance among progressive Milanese patricians and the provincials could never appear in this political forum.

This point can be further bolstered by an analysis of events in the 1790s. The political institutions of Lombard society were shaken once again during the radical reforms of Joseph II. This was a second massive state-led attack on patrician privileges. The reaction to these reforms shows clearly the importance of the structure of Lombard political society in undermining class formation. After Joseph's demise, his brother Leopold II convened a kind of estates general, the Social Deputation, to discuss grievance in the provinces. Pietro Verri and another progressive noble who latter became a high-ranking figure in $\mathrm{Na}-$ poleon's regime, Francesco Melzi, stood as candidates for the delegation. The 
more reactionary wing of the Milanese patriciate defeated them. Verri and Melzi wanted to use the liberalization at the beginning of Leopold's reign to establish political structures based on property ownership rather than privilege; that is, they wanted to return to Neri's project (Cuccia 1971:24-25, 51). Verri and Melzi had the potential support of a large section of the nobility impatient with patrician rule. As Cuccia writes, ". . . [that] the majority of the landowners and part of the patrician stratum itself no longer recognized itself in the request-reactionary and corporative-of the 'deputies' is almost obvious" (Cuccia 1971:41). Instead, however, the conservative Milanese patriciate reinstated patrician power throughout Lombardy (Cuccia 1971:40).

These struggles were not only occurring in Milan. In the early period of Leopold's reign in both Lodi and Como the emperor initiated projects to bring rural landowners into an expanded regional representative body based in the city. Leopold wanted to promote the interests of non-noble landholders. But in Como both patricians and commoners opposed Leopold's attempt to allow commoners into the patrician representative bodies. The non-noble landholders were as jealous of their autonomies as the patricians (Cuccia 1971:91). A similar struggle occurred in Lodi. Here the non-nobles split between some who asked for participation in an expanded council, and others who wanted a separate body for the non-noble landholders from the countryside (Cuccia 1971:92). Thus the very groups that one might expect to have been the most interested in the construction of agrarian capitalist class organizations - non-noble landholders - sometimes struggled for the re-establishment of patrician privileges in exchange for some political autonomy from the dominant city state.

Finally the existence of a potential patriciate and rich commoner alliance that could issue in class formation is suggested by the behavior of Lombard owners under Napoleon in the early part of the nineteenth century. It was under the French that Milan first had a communal council based not on birth but on wealth. Emanuele Pagano (1994:118) shows that from the years 1802 to 1814 membership in the council was relatively balanced among commoners and nobles. As Pagano writes, the council “ . . . acted to amalgamate any ideological differences (which in any case were slight), forging a common mentality." This was precisely the bloc that Pietro Verri and his allies had been struggling to create since the 1760s. As developments in the Napoleonic period show, it was not the 'social basis' that was missing, but the political structures - an appropriate representative chamber in which landowner interests could be articulated politically.

These failed political strategies show how the organization of Lombard political society, specifically the organization of Milanese government, inhibited class formation. Noble interests in Lombardy could only be articulated as a defense of municipal privileges. Thus, although economic, state-centered and cultural factors were conducive to class formation, political society, the structure of noble interest representation, undermined their efficacy in this case. 


\section{DISCUSSION}

This paper asks: what is the impact of political society that is how interests in civil society are translated into claims on the state, on class formation? I have argued that existing literature could be enriched by isolating political society as an explanatory factor. Current theories attempt to explain class formation either as a direct outcome of economic development, as an interaction of state and civil society, or as a matter of culture and consciousness. I have attempted to extend these theories to include an analysis of political society. My argument has been that the economy, the state, and culture were not sufficient in the case of eighteenth-century Austrian Lombardy to lead to the political expression of landowner economic interests.

To establish my claim I employed Negative Case Methodology, selecting a case the outcome of which is anomalous from the point of view of a set of existing theories. Three advantages of the strategy have been apparent here. First, it allows the researcher to discriminate among factors that are often conflated in the positive cases. In the specific case of Austrian Lombardy the evidence shows the importance of political society for explaining class formation, for it was precisely the lack of appropriate structures of representation that undermined class formation in this case. Second, the methodology allows the researcher to draw general theoretical implications from a single case. Thus, having demonstrated the importance of political society in the case of Austrian Lombardy, its role in other cases of class formation could be investigated. Finally, because the methodology operates with a Lakatosian conception of science, it allows researchers to use cases to enrich research programs rather than attempting the dubious, and not necessarily rewarding, task of falsifying theories.

I have organized my historical material accord to this methodology. Building on Lakatos I pursued the strategy of pushing an economic explanation, a political explanation, and a cultural explanation as far as they can go, rather than attempting to falsify these theories. In the end I show that these theories of class formation are singly, and in combination, not as general as they claim to be. Since they all predict class formation as an outcome for Lombardy, yet class formation did not occur, they must be extended to take explicit account of the structure of interest representation: political society.

The economic explanation, derived from the determinist Marxism of the right wing of the third international, would suggest that the embourgeoisment of the nobility should have been a result of a transformation in the relations of production (Bukharin and Preobrazhenky 1969:105-10). However I show that Lombard nobles were deeply involved in capitalist agriculture at both the beginning and end of the century. Since relations of production were, roughly speaking, capitalist, it is a mystery from the point of view of this theory why Lombard nobles did not organize as an economic class. 
The state-centered explanation would suggest that state policies would lead to the formation of a new class identity through pressure to standardize administration and eliminate privileges (Skocpol 1973:18; Mann 1986:481). Lombardy is a classic case of a state-centered attempt to eliminate privileges, and even to create agrarian capitalist political organizations, but this did not result in class formation. Rather, Lombard, and especially Milanese nobles bitterly fought for their 'feudal' privileges throughout the century.

Finally a culturalist explanation might predict class formation as an outcome of the enlightenment transformation of noble self-conceptions in the mid-eighteenth century (Katznelson 1995:146; Lukács 1971:155; Sewell 1985:76-81). Milan was the major intellectual center of the Italian enlightenment, and younger nobles themselves led the movement. Yet the enlightenment political program generated little wide support among the nobility, who retained their patrician privileges rather than becoming an agrarian 'third estate.'

Thus from the point of each explanation taken separately the outcome- the absence of class formation among the Lombard capitalist nobility-is anomalous. The outcome is even more anomalous when one considers the explanations together. It is surely plausible that capitalist development, pressure from a centralizing state, and a sweeping cultural transformation mutually heightened one another's effects. Given this, why didn't class formation occur in Austrian Lombardy?

I suggest that the problem is that these theories do not adequately treat political society - that is the way in which interests are translated into claims on public power. Political society in Austrian Lombardy remained bound to the framework of municipal government based on a structure of legal privileges. This system did not allow class interests to be translated into political claims. Politics in Lombardy overwhelmingly took the form of a struggle among differentially privileged patriciates. There was therefore no political basis for class formation.

Besides my specific claims about class formation, my paper makes a more general claim about the importance of political society. My essay suggests a research program that could motivate a number of research projects. The research program is based on the political Marxism of Gramsci and his followers (Poulantzas 1976; Przeworski 1985; Wright 1978; Stepan-Norris and Zeitlin 1991). But these scholars tend to focus on, as Stepan-Norris and Zeitlin put it, "the relative autonomy of politics" (1991:1153). By this they mean political struggle itself. By contrast, my program would be devoted to an analysis of the political structures that affect how material and ideal interests become politically effective. This question has not always been clearly formulated in the literature, because the structures of interest mediation are very often seen as derivative of the state or civil society or their combination (Skocpol 1985:25). In other work, interests that have clearly undergone a prior political process of aggregation and transformation are treated as 'societal' (Barkey and Parikh 
1991:530). By suggesting that political society can vary independently of either the state or civil society, and that it may affect both, I identify a potentially important research program that could generate better explanations for both class and state formation.

\section{REFERENCES}

Barkey, Karen and Sunita Parikh. 1991. "Comparative Perspectives on the State." Annual Review of Sociology 17:523-49.

Bianchi, Marco. 1976. "Note sull'agricoltura di alcune pievi della pianura irrigua milanese nella prima meta del secolo XVIII." In Le campagne lombarde tra Sette e Ottocento, Mario Romani, ed. Milan: Vita e Pensiero, 3-65.

Bobbio, Norberto. 1999. Teoria generale della politica. Turin: Einaudi.

Bukharin, Nikolai Ivanovich and E. Preobrazhenky. 1969. The ABC of Communism. Translated from the Russian by Eden and Cedar Paul. Baltimore: Penguin Books.

Burawoy, Michael. 1990. "Marxism as Science: Historical Challenges and Theoretical Growth.” American Sociological Review 55:775-93.

Cafagna, Luciano. 1959. "La 'rivoluzione agraria' in Lombardia." Annali-Fondazione Giangiacomo Feltrinelli 2:367-428.

Capra, Carlo. 1979. "Riforme finanziarie e mutamento istituzionale nello stato di Milano: Gli anni sessanta del secolo XVIII." Rivista storica Italiana 2-3:313-68.

1987. La lombardia austriaca nell'eta delle riforme: 1706-1796. Torino: Utet.

Cavanna, Adriano. 1980. "La codificazione del diritto nella Lombardia austriaca." In Economia, istituzioni, cultura in Lombardia nell'eta di Maria Teresa istituzioni e societa, Aldo De Maddalena, Ettore Rotelli and Gennaro Barbarisi, eds. Milan: Mulino, 611-58.

Cuccia, Silvia. 1971. La Lombardia alla fine dell'Ancien Regime: ricerche sulla situazione amminstrativa e giudizaria. Florence: La Nuova Italia Editrice.

Dipper, Chistof. 1982. "Dispotismo e costituzione: Due concetti di libertá nell'illuminismo milanese." In Economia, istituzioni, cultura in Lombardia nell'etá di Maria Teresa: II Cultura e societá. Milan: Mulino, 863-902.

Emigh, Rebecca. 1997. "The Power of Negative Thinking: The Use of Negative Case Methodology in the Development of Sociological Theory." Theory and Society 26: 649-84.

Grab, Alexander I. 1980. "The Politics of Subsistence: Reforms in the Grain Trade and Bread Production in Austrian Lombardy in the Age of Enlightened Absolutism." $\mathrm{Ph} . \mathrm{D}$. diss., University of California at Los Angeles.

. 1983-1984. "Enlightened Despotism and State Building: The Case of Austrian Lombardy." In Austrian History Yearbook 19-20:43-72.

1985. "The Politics of Subsistence: The Liberalization of Grain Commerce Under Enlightened Despotism." Journal of Modern History 57:185-210.

1989. "Enlightened Absolutism and Commonlands Enclosure: The Case of Austrian Lombardy." Agricultural History 63:49-72.

Gramsci, Antonio. 1971. Selections from the Prison Notebooks. New York: International Publishers.

Habermas, Juergen. 1989. The Structural Transformation of the Public Sphere. Cambridge, Mass.: MIT Press.

Katznelson, Ira. 1995. "Levels of Class Formation.” In Class, Patrick Joyce, ed. Oxford: Oxford University Press, 142-49.

Klang, Daniel M. 1977. Tax Reform in Eighteenth-Century Lombardy. New York: Columbia University Press. 
1990. "Cesare Beccaria, Pietro Verri e l'idea dell'imprenditore nell'illuminismo milanese." In Cesare Beccaria tra Milano e l'Europa. Bari: La Terza, 371-406.

Lakatos, Imre. 1981. "History of Science and Its Rational Reconstructions." In Scientific Revolutions, Ian Hacking, ed. New York: Oxford University Press, 107-27.

Limoli, Donald A. 1958. "Pietro Verri: A Lombard Reformer Under Enlightened Absolutism and the French Revolution." Journal of Central European Affairs 18:254-80.

Lukács, Georg. 1971. History and Class Consciousness. Cambridge, Mass.: MIT Press.

Mann, Michael. 1986. The Sources of Social Power Volume I: A History of Power from the Beginning to a.d. 1760. Cambridge: Cambridge University Press.

Marx, Karl. 1978. "Manifesto of the Communist Party." Pp. 469-599 in The Marx Engels Reader, Second Edition, edited by Robert C. Tucker. New York: Norton.

Mozzarelli, Cesare. 1982. Sovrano, società e amminstrazione locale nella Lombardia teresiana (1749-1758). Bologna: Il Mulino.

Pagano, Emanuele. 1994. Il Comune di Milano nell'età napoleonica (1800-1814). Milano: Vita e Pensiero.

Pino, Francesca. 1979. "Il patriziato a Milano nel secolo XVIII.” Societa e storia 5:33978.

Poulantzas, Nicos. 1976. Political Power and Social Classes. London: New Left Books.

Przeworski, Adam. 1985. Capitalism and Social Democracy. Cambridge: Cambridge University Press.

Roberts, J. M. 1953. "Lombardy.” In The European Nobility in the Eighteenth Century, A. Goodwin, ed. London: Adam and Charles Black, 60-82.

Romani, Mario. 1959. L'agricoltura in Lombardia dal periodo delle riforme al 1859: Struttura, organizzazione sociale e tecnica. Milan: Vita e Pensiero.

Sella, Domenico. 1979. Crisis and Continuity: The Economy of Spanish Lombardy in the Seventeenth Century. Cambridge, London: Harvard University Press.

Sewell, William. 1985. "Ideologies and Social Revolutions: Reflections on the French Case." Journal of Modern History 57,1:57-85.

Skocpol, Theda. 1973. "A Critical Review of Barrington Moore's Social Origins of Dictatorship and Democracy." Politics and Society 4,11:1-34.

— 1985. "Bringing the State Back In: Strategies of Analysis in Current Research." In Bringing the State Back In, Peter Evans, Dietrich Rueschemeyer, and Theda Skocpol, eds. New York: Cambridge University Press, 3-37.

Stepan-Norris, Judith and Maurice Zeitlin. 1991. "'Red' Unions and 'Bourgeois' Contracts?" American Journal of Sociology 5:1151-200.

Thompson, E. P. 1963. The Making of the English Working Class. New York: Vintage Books.

Venturi, Franco. 1969. Settecento rifomatore: Da Muratori a Beccaria. Turin: Einaudi. - 1987. Settecento riformatore V: L'Italia dei lumi (1764-1790). Turin: Einaudi.

Weber, Max. [1946] 1968. "Class, Status, Party.” In From Max Weber: Essays in Sociology. Translated from the German by H. H. Gerth and C. Wright Mills, and edited by H. H. Gerth and C. Wright Mills. New York: Oxford University Press, 180-95.

Weir, Margaret and Theda Skocpol. 1985. "State Structures and the Possibilities for 'Keynesian' Responses to the Great Depression in Sweden, Britain, and the United States." In Bringing the State Back In, Peter Evans, Dietrich Rueschemeyer, and Theda Skocpol, eds. New York: Cambridge University Press.

Woolf, Stuart J. 1979. A History of Italy 1700-1860: The Social Constraints of Political Change. New York: Methuen.

Wright, Erik Olin. 1978. Class, Crisis and the State. London: New Left Books. 